\title{
CONSILIUM
}

Berkala Kajian Konseling Dan Ilmu Keagamaan

Avalaible at http://jurnal.uinsu.ac.id/index.php/consilium

ISSN : 2338-0608 (Print) | ISSN : 2654-878X (Online)

\section{Analisis Tingkat Kecemasan Karir Siswa}

\author{
Wan Mariah, Yusmami, Rizky Andana Pohan \\ Institut Agama Islam Negeri Langsa, Indonesia. \\ Korespondensi: wanmariah2016@gmail.com
}

\begin{abstract}
Anxiety is an unpleasant subjective experience of worry or tension in the form of feelings of anxiety, tension, and emotions experienced by a person. Career anxiety can be described as a condition where a person is unable to make decisions because of the interception situation in the decision-making process. Based on the results of research in the field, it appears that there are students who are anxious and worried about their future. They often experience feelings of confusion and doubt about pursuing a career that is right for them. Students often encounter various problems in career selection. This research uses descriptive quantitative method. The subjects of this study were students of State Senior High School 1 Seruway, Seruway District, Aceh Tamiang District, class X and class XI. Based on the results of this study, it can be seen that the career anxiety of Seruway 1 Public Senior High School students as a whole is in the High category with a score of 68.01. Thus it is expected that there will be treatment of these problems so that students can solve the problem. One way of dealing with this problem is with career counseling guidance services.
\end{abstract}

Keywords: Career anxiety, Students; School.

\begin{abstract}
Abstrak: Kecemasan merupakan pengalaman subjektif yang tidak menyenangkan mengenai kekhawatiran atau ketegangan berupa perasaan cemas, tegang, dan emosi yang dialami oleh seseorang. Kecemasan karir sendiri dapat digambarkan sebagai kondisi dimana seseorang tidak mampu membuat keputusan karena situasi intersepsi dalam proses pengambilan keputusan. Berdasarkan hasil penelitian di lapangan, terlihat bahwa terdapat siswa yang cemas dan khawatir dalam memikirkan masa depannya. Mereka kerap mengalami perasaan bingung dan ragu untuk melanjutkan karir yang tepat untuk mereka. Penelitian ini menggunakan metode deskriptif kuantitatif. Subyek penelitian ini adalah siswa Sekolah Menengah Atas Negeri 1 Seruway Kecamatan Seruway Kabupaten Aceh Tamiang kelas X dan kelas XI. Berdasarkan hasil penelitian ini terlihat bahwa kecemasan karir siswa Sekolah Menengah Atas Negeri 1 Seruway secara keseluruhan berada pada kategori Tinggi dengan skor 68,01. Dengan demikian diharapkan adanya penanganan terhadap masalah tersebut sehingga siswa dapat menyelesaikan masalahnya. Salah satu cara penanganan masalah tersebut adalah dengan layanan bimbingan konseling karir
\end{abstract}

Kata kunci: Kecemasan Karir, Konselor, Konseling Karier, Bimbingan dan Konseling. 


\section{PENDAHULUAN}

$\mathrm{S}$ ekolah Menengah Atas (SMA) adalah jenjang pendidikan menengah pada pendidikan formal di Indonesia setelah lulus Sekolah Menengah Pertama (SMP) atau sederajat. SMA ditempuh dalam waktu tiga tahun, mulai dari kelas X sampai kelas XII. Pada tahun kedua yakni kelas XI, siswa SMA dapat memilih salah satu dari tiga jurusan yang ada, yaitu Sains, Sosial, dan Bahasa. Pada akhir tahun ketiga yakni kelas XII, siswa diwajibkan mengikuti Ujian Nasional yang mempengaruhi kelulusan siswa tersebut (Kemendiknas, 2010). Sekolah Menengah Atas juga dipandang sebagai jenjang pendidikan yang penting untuk menghasilkan sumber daya manusia yang berkualitas. Di tengah tuntutan dunia global yang semakin bebas, peran SMA sebagai perantara untuk meneruskan pendidikan ke tingkat yang lebih tinggi dianggap sangat tepat. Pada dasarnya, segala proses yang terjadi dalam dunia pendidikan tingkat SMA merupakan bekal bagi para siswa untuk mampu menghadapi masa yang akan datang. Dalam fungsi sekolah itu sendiri sebagai tempat untuk memperoleh pendidikan, pengetahuan serta pengalaman. Setiap sekolah pastinya memiliki bobot atau standar yang berbeda-beda disetiap tingkatannya. Beban pembelajaran, tingkat kesulitan dan berbagai hal lainnya yang terjadi di ruang lingkup SMA pastinya jauh berbeda, dimana umumnya banyak menimbulkan kekhawatiran atau kecemasan tersendiri bagi para siswanya.

Siswa sebagai salah satu komponen manusiawi yang menempati posisi sentral dalam proses belajar mengajar dimana di dalam proses ini, siswa sebagai pihak yang ingin meraih cita-cita, kedepannya akan memiliki tujuan yang ingin dicapainya secara optimal. Siswa akan menjadi faktor penentu, sehingga dapat mempengaruhi segala sesuatu yang akan berpengaruh pada hasil atau arah pilihan pada karir masa depannya. Seorang siswa bisa memutuskan karir yang sesuai, dimana karir tersebut pastinya membutuhkan sebuah proses. Siswa juga perlu mengenal atau memahami dan mengembangkan diri serta berpikir secara rasional sehingga nantinya mampu memutuskan karir yang berdasarkan kemampuannya masing-masing. Hal ini dapat dipahami bahwa karier adalah sebuah pilihan yang harus ditentukan lebih awal sebelum menjalaninya (Putri, 2018).

Kecemasan adalah hal yang umum terjadi dalam bidang pendidikan. Setiap siswa pastinya pernah merasa cemas ketika mereka bersekolah. Akan tetapi, bagi siswa tertentu, kecemasan dapat menghambat pembelajaran dan prestasi, khususnya ketika menghadapi karir setelah tamat sekolah. Kecemasan adalah hal yang normal di dalam kehidupan, karena kecemasan sangat dibutuhkan sebagai pertanda akan bahaya yang mengancam. Namun ketika kecemasan terjadi terusmenerus, tidak rasional dan intensitasnya meningkat, maka dari itu kecemasan dapat mengganggu aktivitas sehari-hari yang disebut sebagai gangguan kecemasan. Kecemasan juga merupakan gangguan psikologis yang banyak dialami oleh sebagian manusia, termasuk siswa di sekolah.

Dalam artikel (Susan Heitler) yang ditulis oleh seorang pakar psikologis asal Denver dan penulis buku 'From Conflict to Resolution' menjelaskan bahwa gangguan kecemasan adalah yang paling umum dari semua penyakit mental. Kecemasan ini dapat mempengaruhi setidaknya 25\% dari semua remaja pria dan 
$30 \%$ dari semua remaja perempuan. Bahkan, banyak ahli melihat adanya peningkatan tingkat kecemasan serta timbulnya gangguan kecemasan pada orang dewasa dan remaja Serta menurut sebuah survey kesehatan mental yang dilakukan oleh Pew Reseach Center ditahun 2018, remaja saat ini adalah yang paling merasa kecemasan atau gelisah. Mereka (para remaja) mengakuinya sendiri, dalam survey ini ditemukan bahwa 70\% remaja mengatakan kecemasan dan depresi adalah "masalah utama" bagi para remaja, serta hanya $26 \%$ yang mengatakan itu adalah masalah kecil.

Dunia karir membuat setiap individu harus siap dalam berkompetisi agar memiliki peluang baik mendapatkan pekerjaan atau pengalaman yang sesuai dengan keinginan, minat maupun bakat (Ghufron \& Risnawati, 2016). Dalam berkompetisi untuk meraih karir, semua berusaha untuk menjadi yang terbaik dibidangnya. Untuk itu standar keahlian, keterampilan, ketekunan, kesiapan mental dan rasa kompetitif yang baik, bisa menjadi penentu keberhasilan sesorang dalam menekuni karir terbaik. Dalam proses menjadi yang terbaik itulah diperlukan sikap profesional, kompeten, mental pejuang dan memiliki pengalaman di bidangnya tanpa merasa kecemasan sedikitpun. Maka dari itu para siswa di sekolah juga harus melakukan yang terbaik guna mempersiapkan kemungkinan yang akan terjadi dimasa depan terkait karir mereka sendiri, hal inilah yang menjadi salah satu dasar terjadinya permasalahan bagi siswa, dimana pada tahap ini sekolah juga menjadi sumber pemicu kecemasan. Tujuan pendidikan siswa yang menitik beratkan pada keberhasilan atau kemampuan para siswa menghadapi masa depan menjadi tuntutan tersendiri bagi seorang siswa.

Kecemasan karir yang dialami jelas terjadi terhadap siswa-siswi kelas X dan XI Sekolah Menengah Atas Negeri 1 Seruway. Siswa dari kelas X dan XI mengalami kecemasan dalam memutuskan dan memilih karirnya. Siswa-siswa tersebut terlihat cemas dan khawatir dalam memikirkan masa depannya. Mereka kerap mengalami perasaan bingung dan ragu untuk melanjutkan karir yang tepat untuk mereka. Siswa seringkali menemukan berbagai permasalahan dalam pemilihan karir mereka. Permasalahan-permasalahan yang dihadapi akan menghambat siswa dalam mencapai pemilihan karir yang optimal. Kecemasan tersebutlah yang membuat seseorang menjadi tertekan dan akibatnya seseorang takut untuk menatap masa depan secara optimis, akan lebih fatalnya lagi seseorang tersebut akan hilang semangat belajarnya, putus sekolah atau tidak ingin melanjutkan jenjang perguruan tinggi yang jelas-jelas merupakan jembatan menuju masa depan yang lebih cerah demi mencari pekerjaan, dikarnakan kurangnya pemahaman individu tersebut terhadap kemampuan dirinya sendiri. Hal ini sangat perlu mendapat perhatian khusus terutama oleh guru Bimbingan Konseling di sekolah, karena gangguan kecemasan terhadap karir bisa sangat merugikan individu terutama masa depannya apabila tidak dapat dikurangi atau dituntaskan.

Tujuan penelitian ini adalah untuk mengetahui tingkat kecemasan karir yang terjadi pada siswa-siswi kelas X dan XII SMA Negeri 1 Seruway Kabupaten Aceh Tamiang. Manfaat dari penelitian ini agar dapat memperkaya dan memberikan kontribusi ilmu atau referensi ilmiah bagi jurusan Bimbingan Konseling Islam, khususnya mengenai tingkat kecemasan terhadap karir bagi siswa di sekolah. 


\section{METODE PENELITIAN}

Penelitian ini menggunakan pendekatan metode penelitian kuantitatif. Penelitian kuantitatif adalah penelitian dengan memperoleh data yang berbentuk angka, mulai dari proses pengumpulan data, menganalisis data serta menyajikan dari hasil penelitian. Penelitian kuantitatif adalah metode analisis dengan melakukan perhitungan terhadap data-data yang bersifat pembuktian dari masalah.

Desain penelitian yang digunakan pada penelitian ini adalah penelitian Deskriptif Kuantitatif. Dalam (Muri Yusuf, 2014 : 62)) deskriptif kuantitatif adalah salah satu jenis penelitian yang bertujuan mendeskripsikan secara sistematis, faktual, dan akurat mengenai fakta dan sifat populasi tertentu, atau mencoba menggambarkan fenomena secara detail. Didalam penelitian deskriptif kuantitatif memusatkan pemecahan masalah yang ada pada masa sekarang atau masalah kejadian yang aktual dan berarti.

Pengambilan sampel dalam penelitian ini adalah menggunakan teknik Non Probability Purposive Sampling. Penentuan jumlah sampel yang digunakan oleh peneliti adalah berdasarkan metode Slovin sebagai alat ukur untuk menghitung ukuran sampel karena jumlah populasi yang diketahui lebih dari 100 responden. Jumlah siswa kelas X dan XI SMA Negeri 1 Seruway sebanyak 373 orang. Maka dengan menggunakan rumus Slovin, ukuran sampel yang dapat diambil adalah sebanyak 79 orang (Husein Umar, 2013 : 78).

Teknik pengumpulan data dalam penelitian ini adalah dengan kuesioner. Kuesioner (angket) adalah cara pengumpulan data dengan memberikan daftar pertanyaan berupa angket atau daftar isian kepada populasi atau sampel penelitian (responden). Kuesioner yang digunakan dalam penelitian ini adalah kuesioner tertutup, karena jawaban dari pertanyaan-pertanyaan tersebut telah disediakan dengan menggunakan skala likert. Teknik pengumpulan data menggunakan kuesioner (angket) di gunakan dalam mengumpulkan data untuk menjawab rumusan masalah (Minzilati, 2017 : 73).

Analisis data yang digunakan adalah teknik analisis data statistik deskriptif. Yaitu menganalisis data dengan cara mendeskripsikan atau menggambarkan data yang telah terkumpul sebagaimana adanya tanpa bermaksud membuat kesimpulan yang berlaku untuk umum atau generalisasi. Data kuesioner kecemasan karier dianalisis dan dideskripsikan dengan menggunakan rumus persentase. Rumus persentase yang digunakan adalah :

Keterangan :

$$
P=\frac{f}{n} \times 100
$$

$P$ : tingkat persentase jawaban

$f$ : frekuensi jawaban

$n$ : number of cases ( banyaknya individu )

Selanjutnya dalam melakukan kategorisasi diperlukan interval data yang diperoleh dengan rumus berikut :

$$
\text { Interval } K=\frac{\text { data terbesar }- \text { data terkecil }}{\text { jumlah kelompok }}
$$


Untuk mengetahui kategorisasi dan persentase kecemasan karier dengan 12 item pernyataan, skor tertinggi adalah 60 dan skor terendah adalah 12.

\section{HASIL PENELITIAN DAN PEMBAHASAN}

Selanjutnya diperoleh kategorisasi Kecemasan Karir Siswa di Sekolah dapat dijelaskan dalam tabel berikut:

Tabel 1. Kategorisasi Penskoran dan Persentase Kecemasan Karir

\begin{tabular}{c|c|c}
\hline Kategorisasi & \multicolumn{2}{|c}{ Rentang } \\
\cline { 2 - 3 } Kecemasan Karir & Skor & \% Rata-Rata \\
\hline Sangat Tinggi & $>50$ & $83 \%$ \\
Tinggi & $40-49$ & $66 \%$ \\
Sedang & $30-39$ & $50 \%$ \\
Rendah & $20-29$ & 0,00 \\
Sangat Rendah & $<28$ & 0,00 \\
\hline
\end{tabular}

Berdasarkan penyebaran instrumen kecemasan karir siswa dari keseluruhan sampel (responden) berjumlah 79 siswa, maka dapat diperoleh data sebagaiberikut :

Tabel 2. Data Tingkat Kecemasan Karir Siswa

\begin{tabular}{|c|c|c|c|}
\hline Interval Skor & Kategori & $\mathbf{F}$ & $\%$ \\
\hline$>50$ & Sangat Tinggi & 4 & $5 \%$ \\
\hline $40-49$ & Tinggi & 43 & $54 \%$ \\
\hline $30-39$ & Sedang & 32 & $40 \%$ \\
\hline $20-29$ & Rendah & 0 & 0,00 \\
\hline$<28$ & Sangat Rendah & 0 & 0,00 \\
\hline \multicolumn{2}{|c|}{ Total } & 79 & $100,00 \%$ \\
\hline
\end{tabular}

Berdasarkan tabel di atas memperlihatkan bahwa sebagian besar siswasiswi SMAN 1 Seruway memiliki Kecemasan Karier yang tinggi sebanyak 43 orang yaitu sebesar 54\%, siswa berada pada kategori sedang sebanyak 32 orang yaitu sebesar $40 \%$, kemudian pada kategori sangat tinggi sebanyak 4 orang yaitu sebesar 5\%. Untuk lebih rincinya dapat dilihat pada Tabel 3.

Pada Tabel 3 memperlihatkan bahwa secara rata-rata dari keseluruhan indikator, siswa-siswi SMAN 1 Seruway memiliki kecemasan karier yang tinggi yaitu sebesar 41,01. Hal ini dapat dilihat dari hasil analisis data pada masingmasing indikator, antara lain yaitu : Eksplorasi diri siswa sebesar 2.76, rancangan karir sebesar 2.92, kepercayaan diri siswa sebesar 4.08, keputusan karir sebesar 3.47 , tujuan karir sebesar 4.27, ketidaksesuaian pilihan karir pada siswa sebesar 2.69 , semangat karir yang ada pada siswa sebesar 4.25 , penyesuaian karir siswa sebesar 2.97, peluang karir sebesar 3.44, pilihan karir sebesar 3.29, kesempatan karir sebesar 3.52, dan kepuasan karir yaitu sebesar 3.34.

Berdasarkan hasil penelitian yang telah di lakukan maka data dari 79 siswa tersebut kecemasan karir siswa pada kategori tinggi diperoleh rata-rata skor 
41,01 sehingga hal ini mengarah pada kecemasan karir yang tinggi. Siswa di sekolah ini mengalami kecemasan karir, yang di maksud dengan kecemasan karir menurut Thai (2014 : 3) kecemasan karir adalah suatu konstruk yang berbeda dari keraguan karir karena kecemasan karir tidak secara otomatis menghilang setelah keputusan karier. Menurut Thai (2014 : 3), salah satu penyebab munculnya kecemasan karir pada remaja ialah perasaan takut tidak mendapatkan sebuah pekerjaan dikarnakan rendahnya nilai akademis yang diperoleh. Bagi siswa kelas X dan kelas XI, nilai akademis yang diperoleh belum relatif stabil dan belum dianggap sebagai penentu masa depan. Jika dalam kelas tersebut mereka memperoleh nilai akademis yang rendah, maka masih terdapat waktu untuk memperbaiki nilai tersebut. Berbeda dengan kelas XII, apabila mendapatkan nilai akademis rendah, maka dianggap sebagai penentu masa depan dan tidak banyak waktu untuk memperbaikinya.

Tabel 3. Deskripsi Rata-Rata ( Mean) dan Persentase (\%) Kecemasan Karir Berdasarkan Indikator

\begin{tabular}{clcccccccc}
\hline \multirow{2}{*}{ No } & \multicolumn{1}{c}{ Indikator } & Ideal & Max & Min & $\boldsymbol{\Sigma}$ & Mean & \% & SD & Ket \\
\hline 1. & Eksplorasi Diri & 5 & 5 & 1 & 218 & 2,76 & 55,19 & 1,08 & SR \\
2. & Rancangan Karir & 5 & 5 & 1 & 231 & 2,92 & 58,48 & 1,01 & $\mathrm{R}$ \\
3. & Kepercayaan Diri & 5 & 5 & 3 & 322 & 4,08 & 81,52 & 0,78 & $\mathrm{~T}$ \\
4. & Keputusan Karir & 5 & 5 & 2 & 274 & 3,47 & 69,37 & 0,89 & $\mathrm{~S}$ \\
5. & Tujuan Karir & 5 & 5 & 2 & 337 & 4,27 & 85,32 & 0,83 & $\mathrm{~T}$ \\
& Ketidaksesuaian & 5 & 5 & 1 & 213 & 2,69 & 53,92 & 1,07 & $\mathrm{SR}$ \\
6. & Pilihan Karir & & & & & & & & \\
7. & Semangat Karir & 5 & 5 & 3 & 336 & 4,25 & 85,06 & 0,78 & $\mathrm{~T}$ \\
8. & Penyesuaian Karir & 5 & 5 & 1 & 235 & 2,97 & 59,49 & 0,97 & $\mathrm{R}$ \\
9. & Peluang Karir & 5 & 5 & 1 & 272 & 3,44 & 66,86 & 1,10 & $\mathrm{~S}$ \\
10. & Pilihan Karir & 5 & 5 & 2 & 260 & 3,29 & 65,82 & 0,83 & $\mathrm{~S}$ \\
11. & Kesempatan Karir & 5 & 5 & 2 & 278 & 3,52 & 70,38 & 0,90 & $\mathrm{~S}$ \\
12. & Kepuasan Karir & 5 & 5 & 1 & 264 & 3,34 & 66,84 & 1,11 & $\mathrm{~S}$ \\
& Keseluruhan & $\mathbf{6 0}$ & $\mathbf{6 0}$ & $\mathbf{2 0}$ & $\mathbf{3 . 2 4 0}$ & $\mathbf{4 1 , 0 1}$ & $\mathbf{6 8 , 0 1 \%}$ & $\mathbf{1 1 , 3 5}$ & T
\end{tabular}

Menurut Mallet dan Vignoli dalam (Funda Nalbantoglu Yilmaz, 2018), kecemasan karier terkait dengan kecemasan individu tentang karier akademik dan profesional, takut keluarga yang mengecewakan, dan takut menjauh dari keluarga dan teman dekat karena pekerjaan atau kebutuhan akademik. Dengan kata lain, selama tahun-tahun sekolah menengah atas, kecemasan karier mungkin muncul dalam banyak mata pelajaran seperti siswa yang gagal memenuhi harapan keluarga atau tidak mampu mencapai tujuan yang diinginkan, dan tidak dapat memilih pekerjaan yang diinginkan.

Berdasarkan teori di atas bahwa kecemasan karir adalah hal yang negatif, apabila hal ini dibiarkan maka tidak baik bagi siswa. Selanjutnya berdasarkan hasil penelitian (Fenesha, 2018) menunjukkan bahwasanya kecemasan karir memiliki pengaruh terhadap tendency to foreclose melalui peran moderasi kelekatan orang tua. Commitment To Career Choice dapat mempengaruhi kecemasan karir mahasiswa yang memiliki kategori tinggi. Sejalan dengan itu 
maka diperlukannya penurunan atau pelayanan untuk mengatasi masalah tersebut.

Berdasarkan penelitian (Fenesha Flourencia, 2019) menunjukkan hasil bahwasanya kecemasan karir memiliki pengaruh terhadap tendency to foreclose melalui peran moderasi kelekatan orang tua. Kesimpulan penelitian ini adalah Commitment To Career Choice dapat mempengaruhi kecemasan karir mahasiswa yang memiliki kategori tinggi. Untuk melihat kecemasan karir pada penelitian ini, peneliti juga menggunakan salah satu alat ukur yang sama dengan penelitian tersebut berupa kuesioner self-report yaitu Career Anxiety Scale (CAS) yang dibuat oleh Thai (2014). Alat ukur ini dibuat dengan tujuan mengetahui kecemasan karir yang dapat muncul pada siswa di sekolah. Sehingga hasil penelitian yang didapat menunjukkan kecemasan karier yang tinggi terhadap siswa.

Pada penelitian (Fatmawati, 2016) menunjukkan hasil bahwa dukungan sosial mempunyai pengaruh negatif dan signifikan terhadap kecemasan karir siswa. Hal ini ditunjukkan dengan taraf signifikasi 0,000 ( $p<0,05)$ dan persamaan garis regresinya $Y: 118,023+(-0,655) \mathrm{X}$ yang berarti jika dukungan sosial dinaikkan sebesar satu satuan maka kecemasan karir akan menurun sebesar 0,655. Kesimpulan penelitian tersebut adalah dukungan sosial dapat mempengaruhi kecemasan karir siswa, dan mayoritas dukungan sosial dan kecemasan karir siswa kelas XI Akuntansi SMK Negeri 1 Bantul memiliki kategori sedang.

Adapun pada penelitian (Hartono, 2015) hasil penelitiannya menunjukkan bahwa sebagian besar siswa SMA sebesar $47,25 \%$ menggunakan pola demokratis dalam pemilihan karier atas hasil konsultasi dengan guru. Persamaan penelitian tersebut dengan penelitian ini adalah sama-sama meneliti tentang karier siswa. Sementara pada penelitian (Nilla Agustin, 2019) menunjukan hasil analisis adanya pengurangan kecemasan karir masa depan antara sebelum dan sesudah mendapatkan treatmen. Hal ini dibuktikan berdasarkan analisis data menggunakan uji paired sample t-test dapat diperoleh hasil thitung $>$ ttabel yaitu $22,767>2,056$, dengan nilai signifikan dua sisi $(2$-tailed) $<0,05(0,000<0,05)$, sehingga hipotesis nihil (H0) dan hipotesis alternative (Ha) diterima yang artinya Terapi Shalat Dhuha berpengaruh dalam mengurangi Kecemasan Karir Masa Depan di SMA Muhammadiyah 8 Gresik. Kesimpulannya adalah terapi shalat dhuha dapat mempengaruhi kecemasan karir masa depan siswa, sehingga hasil kecemasan karir termasuk dalam kategori rendah.

Sedangkan pada hasil penelitian (Putri dan Ragil, 2016) menunjukkan hasil perasaan cemas yang dialami oleh siswa tidak diikuti dengan gejala-gejala berat yang dapat menganggu aktivitas atau bahkan menganggu jalannya ujian nasional. Layanan bimbingan karier bisa menjadi salah satu cara dalam mempersiapkan siswa dalam menghadapi ujian nasional, dan juga ujian akhir lainnya yang bertujuan sebagai langkah awal siswa dalam mempersiapkan jenjang kariernya. Penelitian ini menggunakan pendekatan kualitatif deskriptif, jadi penelitian ini tidak digambarkan hasil berdasarkan kategori. Kesimpulannya, hasil penelitian tersebut mengurangi kecemasan karir siswa SMA dalam menghadapi ujian nasional dengan memberikan layanan bimbingan karir. 
Kecemasan karir dipengaruhi oleh beberapa hal diantaranya kekhawatiran akan kegagalan, frustasi pada hasil tindakan yang lalu, evaluasi diri yang negatif, perasaan diri yang negatif tentang kemampuan yang dimilikinya, dan orientasi diri yang negatif. Konsekuensi negatif dari kecemasan karier menyarankan pentingnya mengukur karier kegelisahan. Begitu orang-orang sadar bahwa mereka mengalami kecemasan karier, mereka dapat memperoleh bantuan mengurangi kecemasan mereka dan untuk mengurangi dampak negatif dari kecemasan tersebut. Apalagi yang membedakan kecemasan karier dari keraguraguan karier akan memastikan intervensi dilayani untuk semua orang mengalami kecemasan karier daripada hanya mereka yang berjuang untuk memutuskan karier.

Berdasarkan penelitian ini yang dapat dikaitkan dengan penelitian lainnya terungkap bahwa kecemasan karir tidak terjadi pada siswa saja akan tetapi kecemasan karir juga terjadi kepada mahasiswa, sehingga dalam dunia pendidikan kecemasan karir merupakan hal yang wajar akan tetapi dengan kewajaran tersebut perlunya mengatasi masalah tersebut. Oleh sebab itu, persiapan yang baik merupakan salah satu alternatif untuk mengurangi kecemasan, salah satu bentuk intervensi pelayanan konseling untuk pencegahan dan pengentasannya dapat diberikan melalui layanan bimbingan kelompok (Sitorus, 2019; Pohan, dkk, 2020).

\section{KESIMPULAN}

Berdasarkan hasil penelitian yang diperoleh, maka dapat disimpulkan bahwa siswa-siswi SMAN 1 Seruway memiliki keberagaman dalam kecemasan karier. Adapun secara kategori keseluruhan sebanyak 79 orang siswa-siswi SMAN 1 Seruway, siswa yang memiliki kecemasan karier tinggi sebanyak 43 orang yaitu sebesar 54\%, siswa yang berada pada kategori sedang sebanyak 32 orang yaitu sebesar $40 \%$, dan siswa yang berada pada kategori sangat tinggi sebanyak 4 orang yaitu sebesar 5\%. Namun secara keseluruhan dengan nilai rata-rata 41,01 yang diperoleh sebesar 68,01\% menunjukkan bahwa siswa-siswi SMAN 1 Seruway memiliki tingkat kecemasan karir yang tinggi.

Siswa-siswi SMAN 1 Seruway memiliki kecemasan karir yang tinggi disebabkan karena siswa-siswi tersebut masih termasuk dalam state anxiety yaitu reaksi emosi mereka masih bersifat sementara yang timbul pada situasi tertentu saja dan dirasakan karna adanya ancaman tertentu. Keadaan tersebut ditentukan oleh perasaan tegang yang subjektif. Perbedaannya dengan trait anxiety adalah kecemasan sebagai trait ini menunjukkan tingkat kecemasan dan kecendrungan untuk menjadi seorang pencemas, sedangkan kecemasan sebagai state merupakan perasaan cemas yang tidak selalu ada, akan tetapi sering timbul karna adanya ancaman tertentu. Kaitannya dengan karir adalah kecemasan sebagai state menjadi prediktor yang lebih kuat dalam menentukan karir seseorang dibandingkan dengan kecemasan sebagai trait. Hal tersebut disebabkan karna kecemasan sebagai perasaan yang terjadi saat ini (state) lebih mudah dipengaruhi dan berubah dibandingkan kepribadian seseorang yang pencemas (trait). Jadi, dapat disimpulkan bahwa kecemasan karir sebagai state yang dialami siswa-siswi 
SMAN 1 Seruway masih ada kesempatan untuk diperbaiki atau dikurangi agar tidak semakin tinggi.

Berdasarkan hal tersebut maka perlunya adanya peninjauan dan pemberian layanan atau cara mengatasi masalah ini sehingga kecemasan karir yang dialami siswa tidak semakin tinggi yang dapat berdampak negatif pada siswa tersebut, untuk itu perlunya guru bimbingan dan konseling, kepala sekolah, dan konselor untuk bekerjasama dalam mengatasi masalah tersebut.

Dengan demikian maka perlunya di atasi masalah ini sehingga kita dapat membantu kesuksesan siswa, salah satu cara yang mengatasi adalah memberikan layanan informasi, layanan bimbingan karir, dan layanan- layanan lainnya yang berkaitan dengan bimbingan dan konseling.

\section{DAFTAR PUSTAKA}

Flourencia, Fenesha dan Effraim Mirah. 2018. Pengaruh Kecemasan Karir Terhadap Commitment to Career Choice demean Kelekatan Orang Tua sebagai Moderator. 2(1).

Heitler, Susan. "High School and College Student Anxiety: Why the Epidemic?"melalui halaman https://www.psychologytoday.com/ ; diakses pada 3 April 2020.

Koenig, Karl. 2000. Anxiety and Personality Das Konzept Vom Steuernden Objekt Und Seine Anwendungen6. Göttingen.

M, Hartoyo. 2004. Asuhan Keperawatan Klien Anxietas (Kecemasan). Dinas Kesehatan Propinsi Jawa Tengah.

M., Thai, Unno, S., Montgomery, S., Benitez, B. 2014. The Development and Validation of a Scale of Career Anxiety. Unpublished Manuscript : Northwestern University Evanston.

Manzilati, A. 2017. Metodologi Penelitian Kualitatif Paradigma, Metode, dan Aplikasi. UB Press.

Muhith, Abdul. 2015. Pendidikan Keperawatan Jiwa; Teori dan Aplikasi. Andi Offset.

Musfir, Dr. bin Said Az Zahrani. 2005. Konseling Terapi. Gema Insani Pers.

Pohan, R., \& Indra, S. 2020. Efektivitas Layanan Bimbingan Kelompok dalam Meningkatkan Kegiatan Merespon Pembelajaran. Islamic Counseling: Jurnal Bimbingan Konseling Islam, 4(1), 17-30. doi:http://dx.doi.org/10.29240/jbk.v4i1.1280

Purwanta, Edi. 2012. "Faktor yang Mempengaruhi Eksplorasi Karier Siswa SLTP". Jurnal FIP Universitas Negeri Yogyakarta. No. 2. 
Putri, R. D., \& Sari, S. P. 2018. Implementation of John Holland's Career Theory in Guidance and Counseling. ENLIGHTEN: Jurnal Bimbingan Konseling Islam, $1(2), 126-132$.

Setyawan, Febri Endra Budi. 2017. Pedoman Metodologi Penelitian: Statistika Praktis. Zifatama Jawara.

Sitorus, M. W., Badrujaman, A., \& Fitri, S. 2019. Pengaruh Layanan Bimbingan Kelompok dengan Metode Permainan Terhadap Penerimaan Diri Siswa. ENLIGHTEN: Jurnal Bimbingan Konseling Islam, 2(1), 18-23. https://doi.org/10.32505/enlighten.v2i1.1215.

Sugiyono. 2016. Metode Penelitian Administrasi. Alfabeta.

Sugiyono. 2013. Metode Penelitian Kuantitatif Kualitatif dan $R \& D$. Alfabeta

Sugiyono. 2015. Metode Penelitian Pendidikan. Alfabeta.

Yilmaz, Funda Nalbantoglu. 2018. Hicran Cetin Gunduz, Career Indecision and Career Anxiety in High School Students: An Investigation Through Structural Equation Modelling. Eurasian Journal of Educational Research, 78(2), 23-42.

Yusuf, A.Muri. 2014. Metode Penelitian : Kuantitatif, Kualitatif, dan Penelitian Gabungan. Prenadamedia Group. 